\title{
Further Characterization of Dopamine Release by Permeabilized PC12 Cells
}

\author{
Gudrun Ahnert-Hilger and Manfred Gratzl
}

Abteilung Anatomie und Zellbiologie der Universität Ulm, Ulm, F.R.G.

\begin{abstract}
Rat pheochromocytoma cells (PC12) permeabilized with staphylococcal $\alpha$-toxin release $\left[{ }^{3} \mathrm{H}\right]$ dopamine after addition of micromolar $\mathrm{Ca}^{2+}$. This does not require additional $\mathrm{Mg}^{2+}$-ATP (in contrast to bovine adrenal medullary chromaffin cells). We also observed $\mathrm{Ca}^{2+}$-dependent $\left[{ }^{3} \mathrm{H}\right]$ dopamine release from digitonin-permeabilized PC 12 cells. Permeabilization with $\alpha$-toxin or digitonin and stimulation of the cells were done consecutively to wash out endogenous $\mathrm{Mg}^{2+}$-ATP. During permeabilization, ATP was removed effectively from the cytoplasm by both agents but the cells released $\left[{ }^{3} \mathrm{H}\right]$ dopamine in response to micromolar $\mathrm{Ca}^{2+}$ alone. Replacement by chloride of glutamate, which could
\end{abstract}

sustain mitochondrial ATP production in permeabilized cells, does not significantly alter catecholamine release induced by $\mathrm{Ca}^{2+}$. However, $\mathrm{Mg}^{2+}$ without ATP augments the $\mathrm{Ca}^{2+}$-induced release. The release was unaltered by thiol-, hydroxyl-, or calmodulin-interfering substances. Thus $\mathrm{Mg}^{2+}-\mathrm{ATP}$, calmodulin, or proteins containing $-\mathrm{SH}$ or $-\mathrm{OH}$ groups are not necessary for exocytosis in permeabilized PC12 cells. Key Words: Exocytosis-PC12- $\mathrm{Ca}^{2+}-$ $\mathrm{Mg}^{2+}$-ATP-Permeabilized cells. Ahnert-Hilger G. and Gratzl M. Further characterization of dopamine release by permeabilized PC12 cells. J. Neurochem. 49, 764-770 (1987).
Fusion of secretory vesicle membranes with the plasma membrane is the final event in stimulusexocytosis coupling. This process is not easy to investigate in intact cells because the interacting membrane surfaces are not accessible. Various procedures have therefore been developed to permeabilize the plasma membrane without affecting the exocytotic machinery and it has been shown that micromolar $\mathrm{Ca}^{2+}$ as well as $\mathrm{Mg}^{2+}$-ATP are necessary to elicit exocytosis in the bovine adrenomedullary chromaffin cell permeabilized by high-voltage discharge (Baker and Knight, 1978, 1981; Knight and Baker, 1982), saponins (Brooks and Treml, 1983a; Dunn and Holz, 1983; Wilson and Kirshner, 1983), or $\alpha$-toxin (Bader et al., 1986). By contrast, rat pheochromocytoma cells (PC12) permeabilized by $\alpha$-toxin require only $\mathrm{Ca}^{2+}$ for the release reaction (Ahnert-Hilger et al., 1985a,b). This lack of dependence on exogenous $\mathrm{Mg}^{2+}$-ATP indicates that $\mathrm{Ca}^{2+}$ and $\mathrm{Mg}^{2+}$-ATP may catalyze different steps in secretory cells prior to the final event of membrane fusion.

However, endogenous stores of $\mathrm{Mg}^{2+}$-ATP might still be available for the release reaction in $\alpha$-toxin- permeabilized $\mathrm{PC} 12$ cells. To exclude this possibility the cells were depleted of endogenous ATP before they were stimulated with $\mathrm{Ca}^{2+}$. Glutamate, present during previous experiments, was exchanged for chloride to exclude production of ATP for the $\mathrm{Ca}^{2+}$-induced release by enhancement of mitochondrial ATP production. Calmodulin-activated release in intact chromaffin cells (Kenigsberg et al., 1982; Brooks and Treml, 1983b) was studied using trifluoperazine (TFP). $N$-Ethylmaleimide (NEM), which interferes with exocytosis in electrically permeabilized bovine chromaffin cells (Knight and Baker, 1982), and 4(hydroxymercuri)benzoic acid (PHMB), which inhibits fusion of isolated vesicles (Gratzl and Dahl, 1978), were used to test if proteins containing $-\mathrm{SH}$ or $-\mathrm{OH}$ groups are involved in dopamine release from permeabilized PC1 2 cells.

\section{MATERIALS AND METHODS}

PC1 2 cells were kept in culture as described by AhnertHilger et al. (1985b). Permeabilized cells were studied either in suspension or grown on poly-L-lysine $70-40,000 \mathrm{MW}$ -
Received November 6, 1986; revised March 11, 1987; accepted March 11, 1987.

Address correspondence and reprint requests to Dr. G. AhnertHilger at Abteilung Anatomie und Zellbiologie der Universität Ulm, Postfach 4066, D-7900 Ulm, F.R.G.
Abbreviations used: BSA, bovine serum albumin; DMEM, Dulbecco's modified Eagle's medium; DTNB, 2,2'-dinitro- $S$, $S^{\prime}$-dithiobenzoic acid: NEM, $N$-ethylmaleimide; NTA, nitriloacetic acid; PHMB, 4-(hydroxymercuri)benzoic acid; PIPES, 1,4-piperazinediethanesulfonic acid; TFP, trifluoperazine. 
precoated $16-\mathrm{mm}$ multiwell plates. Cells $\left(5 \times 10^{5}\right.$ cells/well or $2-3 \times 10^{5}$ cells in suspension corresponding to about 100 $\mu \mathrm{g}$ of protein/sample) were loaded with $\left[{ }^{3} \mathrm{H}\right]$ dopamine in Dulbecco's modified Eagle's medium (DMEM) (serumfree) supplemented with $1 \mathrm{mM}$ ascorbic acid for $2 \mathrm{~h}$ at $37^{\circ} \mathrm{C}$. After three washes with $\mathrm{Ca}^{2+}$-free potassium glutamate buffer [mmol/L: potassium glutamate 150, 1,4-piperazinediethanesulfonic acid (PIPES) 10, EGTA 0.5, nitriloacetic acid (NTA) 5, pH 7.2 titrated with $\mathrm{KOH}$ ] cells were preincubated for 10-15 min in the same buffer supplemented with $0.2 \%$ bovine serum albumin (BSA) at $37^{\circ} \mathrm{C}$. After removal of the preincubation buffer the given amount of $\mathrm{Ca}^{2+}$ and $\mathrm{Mg}^{2+}$ in potassium glutamate medium plus $0.2 \%$ BSA with or without $\alpha$-toxin $(150-200 \mathrm{U} / \mathrm{ml})$ was added to the cells. The toxin batch used contained 30,000 hemolytic units $/ \mathrm{mg}$ of protein (Lind et al., 1987). Incubation was stopped after $20 \mathrm{~min}$ by centrifugation and the radioactivity in the supernatant medium and in the cells (after lysis with $0.2 \%$ sodium dodecyl sulfate) was determined by liquid scintillation counting. In another experimental design cells were treated first with $\alpha$-toxin dissolved in $\mathrm{Ca}^{2+}$-free potassium glutamate buffer. After $20 \mathrm{~min}$ at $37^{\circ} \mathrm{C}$ or $30^{\circ} \mathrm{C}$ the medium was completely removed and cells were stimulated with the desired $\mathrm{Ca}^{2+}, \mathrm{Mg}^{2+}$, and $\mathrm{Mg}^{2+}-\mathrm{ATP}$ concentrations in potassium glutamate buffer. Cells stimulated in suspension or on plates gave similar results. This holds also for experiments carried out at $30^{\circ} \mathrm{C}$ instead of $37^{\circ} \mathrm{C}$.

The free $\mathrm{Ca}^{2+}$ and $\mathrm{Mg}^{2+}$ concentrations were calculated by a computer program according to Flodgaard and Fleron (1974), kindly provided by T. Saermark, University of Copenhagen, Denmark, using the stability constants given by Sillen and Martell (1971). The media were also controlled with a $\mathrm{Ca}^{2+}$-sensitive electrode (Simon et al., 1978). The neutral carrier incorporated into a polyvinyl chloride membrane was kindly provided by Dr. W. Simon, ETH Zürich, Switzerland. $\alpha$-Toxin was purified from culture supernatants of Staphylococcus aureus strain Wood 46 using the FPLC technique (Lind et al., 1987). The toxicity was checked with $2.5 \%$ rabbit erythrocytes and calculated as described by Wadström (1968). Protein was determined according to Lowry et al. (1951) using BSA as standard. ATP was measured in the cells (extracted with Tris, $50 \mathrm{mmol} / \mathrm{L}$, $\mathrm{pH} 7.8$; magnesium acetate, $10 \mathrm{mmol} / \mathrm{L}, \mathrm{EGTA}, 1.5 \mathrm{mmol} /$ $\mathrm{L})$ as well as in the supernatants after heating to $95^{\circ} \mathrm{C}$ for 5 min using the firefly assay (Boehringer, Mannheim, F.R.G.) as described by Lind et al. (1987).

\section{Materials}

BSA was obtained from Sigma, München, F.R.G., PHMB and NEM from Serva Heidelberg, F.R.G., 2,2'-dinitro-S, $S^{\prime}$-dithiobenzoic acid (DTNB) from Roth, Karlsruhe, F.R.G. DMEM dried medium, horse serum, and fetal calf serum were supplied by Seromed Biochrom KG, Berlin, F.R.G., culture dishes by Falcon, Becton Dickinson, Heidelberg, F.R.G., and $\left[{ }^{3} \mathrm{H}\right]$ dopamine $(30 \mathrm{Ci} / \mathrm{mmol})$ from New England Nuclear, Dreieich, F.R.G.

\section{RESULTS}

\section{Effects of $\mathrm{Ca}^{2+}$ and $\mathrm{Mg}^{2+}$-ATP on dopamine release from permeabilized $P C 12$ cells}

In permeabilized $\mathrm{PC} 12$ cells release of $\left[{ }^{3} \mathrm{H}\right]-$ dopamine can be triggered by elevating the free $\mathrm{Ca}^{2+}$ concentration in the medium above $0.1 \mu M$ (see also
Ahnert-Hilger et al., 1985a,b). In previous experiments, permeabilization and addition of $\mathrm{Ca}^{2+}$ were carried out simultaneously. When cells were first permeabilized with $\alpha$-toxin in the absence of $\mathrm{Ca}^{2+}$, the subsequent addition of micromolar $\mathrm{Ca}^{2+}$ was sufficient to elicit $\left[{ }^{3} \mathrm{H}\right]$ dopamine release (Fig. 1). The $\mathrm{Ca}^{2+}$ dependency under these experimental conditions strongly resembled that found with $\mathrm{PC} 12$ cells described earlier (Ahnert-Hilger et al., 1985a,b). An increase plateauing at 4-10 $\mu M$ free $\mathrm{Ca}^{2+}$ was followed by a second rise at approximately $10 \mu M$ and becoming maximal at about $100 \mu \mathrm{M}$. The first rise was half maximal at about $1 \mu M \mathrm{Ca}^{2+}$ (Fig. 1). Additional $\mathrm{Mg}^{2+}-$ ATP was not present in this experiment. Since catecholamine release from adrenal medullary chromaffin cells permeabilized by different techniques depends on $\mathrm{Mg}^{2+}$-ATP (see introduction) we investigated in more detail the effect of $\mathrm{Mg}^{2+}$-ATP during release from $\mathrm{PC} 12$ cells.

A comparison of the effects of $\mathrm{Ca}^{2+}$ in the presence or absence of $\mathrm{Mg}^{2+}-\mathrm{ATP}$ is given in Fig. 2a-c. Addition of ATP was not necessary to sustain $\mathrm{Ca}^{2+}$-induced $\left[{ }^{3} \mathrm{H}\right]$ dopamine release. In the absence of $\mathrm{Ca}^{2+}$ the release from $\alpha$-toxin treated cells resembled that of control cells. However, micromolar levels of free $\mathrm{Ca}^{2+}$ induced release of $\left[{ }^{3} \mathrm{H}\right]$ dopamine independent of the presence of ATP, whether $\mathrm{Ca}^{2+}$ stimulation occurred simultaneously with $\alpha$-toxin treatment (Fig. $2 a)$ or after the buffer was replaced following permea-

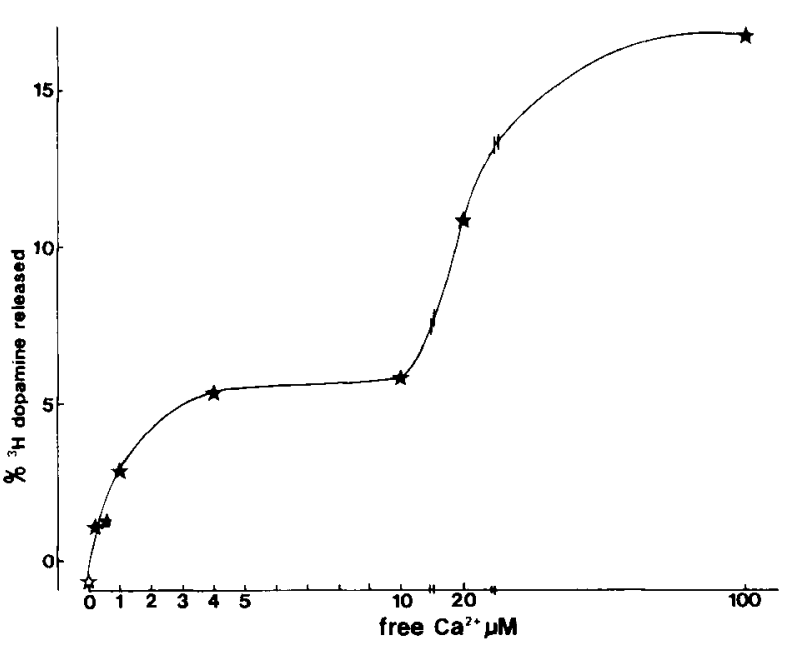

FIG. 1. $\mathrm{Ca}^{2+}$ dependency of $\left[^{3} \mathrm{H}\right]$ dopamine release from $\mathrm{PC} 12$ cells previously permeabilized with $\alpha$-toxin. Cells grown on plates and preloaded with $\left[{ }^{3} \mathrm{H}\right]$ dopamine were washed three times with potassium glutamate buffer (see Materials and Methods). Then they were treated with $\alpha$-toxin $(170 \mathrm{U} / \mathrm{ml})$ in the same buffer supplemented with $0.2 \%$ BSA for $20 \mathrm{~min}$ at $30^{\circ} \mathrm{C}$. The permeabilization medium was then exchanged for fresh potassium glutamate buffer containing the amount of the free $\mathrm{Ca}^{2+}$ concentration given. After a further $10 \mathrm{~min}$ at $30^{\circ} \mathrm{C}$ the radioactivity was counted in the supernatant and in the cell lysate. Each point represents the net release above control of one representative experiment. Release in control samples (in the absence of $\alpha$-toxin) was $8.3 \pm 0.7 \%, n$ $=6(\mathrm{SD})$ 


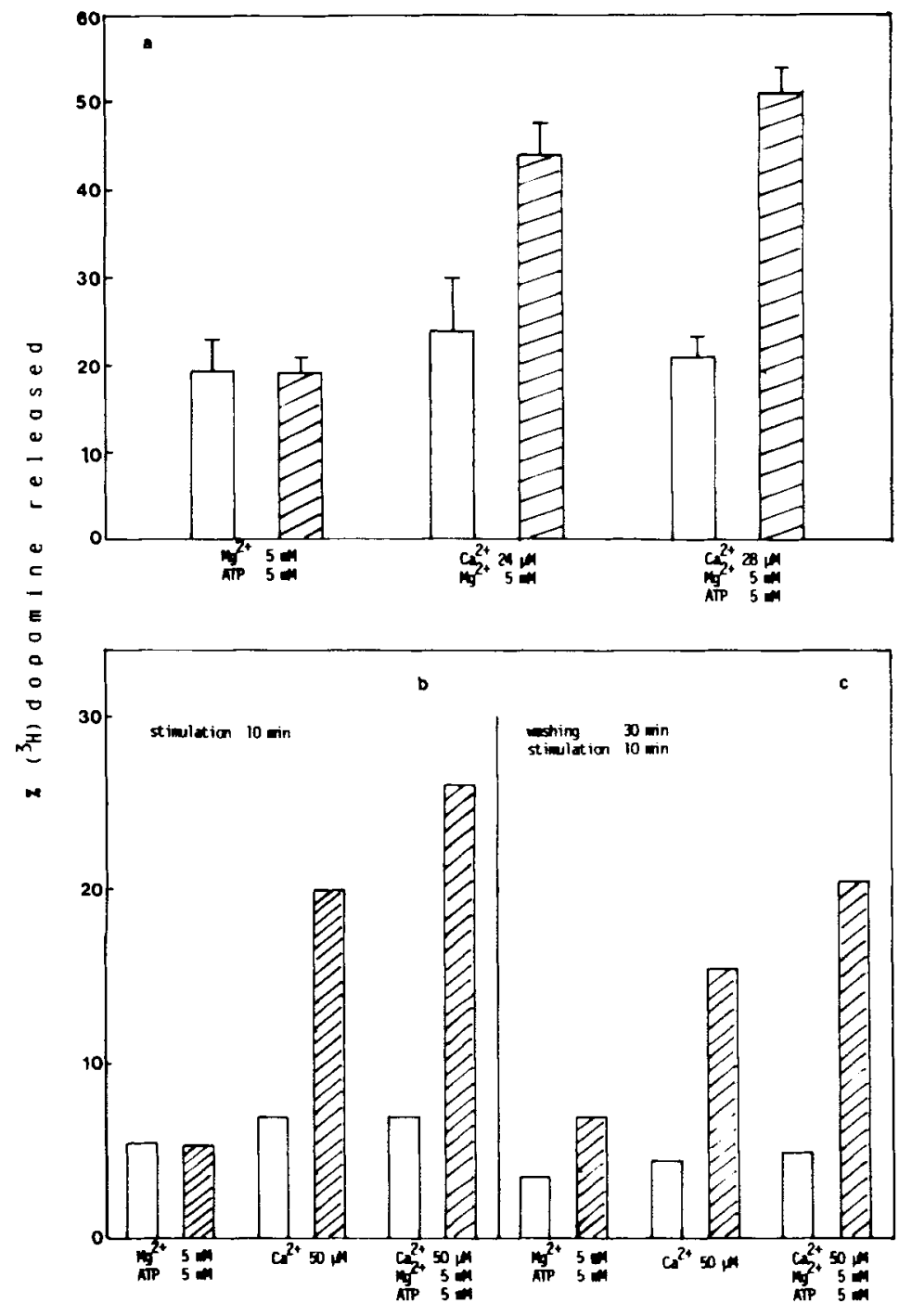

FIG. 2. Failure of $\mathrm{Mg}^{2+}$-ATP to modify $\mathrm{Ca}^{2+}$-induced $\left[{ }^{3} \mathrm{H}\right]$ dopamine release by $\alpha$-toxin-permeabilized PC12 cells. a: Preloaded PC12 cells on plates were treated for $20 \mathrm{~min}$ with $\alpha$-toxin $(150 \mathrm{U} / \mathrm{ml})$ with or without ATP and in the presence of the free $\mathrm{Ca}^{2+}$ concentrations given. The hatched bars represent the permeabilized cells, the open ones controls. The potassium glutamate buffer contained $11 \mathrm{mM}$ glucose, $5 \mathrm{mM}$ EGTA, and $5 \mathrm{mM} \mathrm{Mg}^{2+}$. b: PC12 cells were first treated with $\alpha$-toxin $(150 \mathrm{U} / \mathrm{ml})$ in potassium glutamate buffer (5 mM EGTA) supplemented with $2.5 \mathrm{mM}$ magnesium acetate for $20 \mathrm{~min}$ at $37^{\circ} \mathrm{C}$. The permeabilization medium was replaced by potassium glutamate buffer supplemented with the ions indicated and incubated for a further $10 \mathrm{~min}$ at $37^{\circ} \mathrm{C}$. c: Cells were further washed for $30 \mathrm{~min}$ in the permeabilization buffer with out toxin and $\mathrm{Ca}^{2+}$ and then stimulated under the same conditions with the given amount of $\mathrm{Ca}^{2+}$. The hatched bars represent the $\alpha$-toxin-treated, the open bars control samples. The bars represent two $(b, c)$ or three (a) experiments (SD) bilization (Fig. $2 \mathrm{~b}$ and c). Even after prolonged washing (Fig. 2c) $\mathrm{Mg}^{2+}-\mathrm{ATP}$ only slightly augmented the $\mathrm{Ca}^{2+}$-induced release of $\left[{ }^{3} \mathrm{H}\right]$ dopamine.

Indeed, $\alpha$-toxin renders PC12 cells permeable to ATP as does digitonin, which also causes loss of cytoplasmic macromolecules (Ahnert-Hilger et al., $1985 b$ ). As outlined in Table 1 both agents cause comparable releases of ATP. The subsequent substitution of fresh buffer supplemented with $20 \mu M$ free $\mathrm{Ca}^{2+}$ triggered $\left[{ }^{3} \mathrm{H}\right]$ dopamine release in both permeabilized cell preparations. This clearly indicates that the permeabilization procedure is sufficient to deplete cellular cytoplasmic ATP and that $\mathrm{Ca}^{2+}$ alone leads to secretion.

To rule out the possibility that glutamate in the buffer stimulated ATP production by mitochondria and thus caused apparent ATP independence of dopamine release in previous investigations it was replaced by chloride. However, the release of dopamine as a function of the free $\mathrm{Ca}^{2+}$ concentration was very similar under both conditions (Fig. 3), which confirms
TABLE 1. Comparison of ATP depletion and $\mathrm{Ca}^{2+}$ induced $l^{3} H J$ dopamine release in $P C 12$ cells permeabilized either with digitonin or with $\alpha$-toxin

\begin{tabular}{cccc}
\hline & & \multicolumn{2}{c}{$\begin{array}{c}{\left[{ }^{3} \mathrm{H}\right] \text { Dopamine released }} \\
(\%)\end{array}$} \\
\cline { 3 - 4 } $\begin{array}{c}\text { Treatment } \\
\text { of cells }\end{array}$ & $\begin{array}{c}\text { ATP released } \\
(\%)\end{array}$ & $\mathrm{No} \mathrm{Ca}^{2+}$ & $20 \mu \mathrm{MCa}^{2+}$ \\
\hline- & $20 / 17$ & $6.0 / 7.1$ & $8.0 / 7.3$ \\
Digitonin $(15 \mu M)$ & $65 / 78$ & $7.8 / 7.4$ & $17.1 / 19.0$ \\
- & $22 / 18$ & $4.8 / 7.2$ & $6.4 / 8.6$ \\
$\alpha$-Toxin $(200 \mathrm{U} / \mathrm{ml})$ & $78 / 73$ & $4.2 / 4.8$ & $20.0 / 17.5$ \\
\hline
\end{tabular}

PC12 cells were permeabilized either for $20 \mathrm{~min}$ at $30^{\circ} \mathrm{C}$ with digitonin or for $30 \mathrm{~min}$ at $30^{\circ} \mathrm{C}$ with $\alpha$-toxin (see Materials and Methods). The total ATP content of the cells was about $17 \mathrm{nmol} /$ mg protein $(100 \%)$, which is in the range of values reported earlier (Reynolds et al., 1982). ATP was determined as described in Materials and Methods. For dopamine release the buffer was exchanged for a fresh one with or without $20 \mu M$ free $\mathrm{Ca}^{2+}$. Experiments were in duplicate; each value represents one sample containing $6 \times 10^{5}$ cells for the ATP determination and $3 \times 10^{5}$ cells for the determination of $\left[{ }^{3} \mathrm{H}\right]$ dopamine released. 
earlier observations of the insensitivity of dopamine release from $\alpha$-toxin-permeabilized PC12 cells to the anion present (Ahnert-Hilger et al., 1985b). The increase in the $\mathrm{Ca}^{2+}$-independent basal release in chloride media indicates that chromaffin vesicles are probably less stable in chloride than in glutamate media. Hence, the $\alpha$-toxin-permeabilized PC12 cells differ from identically treated primary cultures of bovine chromaffin cells, as after prolonged washing these required $\mathrm{Mg}^{2+}$-ATP for the $\mathrm{Ca}^{2+}$-induced release of noradrenaline and chromogranin A (Bader et al., 1986).

Effects of free $\mathrm{Mg}^{2+}$ on $\mathrm{Ca}^{2+}$-induced dopamine release from permeabilized $\mathrm{PC} 12$ cells

To define more closely the small effect of $\mathrm{Mg}^{2+}$. ATP observed above and to see whether $\mathrm{Mg}^{2+}$-ATP can modulate exocytosis in PC12 cells, we studied the release of dopamine as a function of the free $\mathrm{Ca}^{2+}$ concentration in the absence or presence of $5 \mathrm{mM} \mathrm{Mg}^{2+}$. ATP (Fig. 4a). Free $\mathrm{Mg}^{2+}$ concentration in the latter buffer is about $0.2 \mathrm{mM}$. Under these conditions, $\mathrm{Ca}^{2+}$ induced release of secretory product increased. In the parallel experiment (Fig. 4b) $1 \mathrm{mM}$ free $\mathrm{Mg}^{2+}$ without

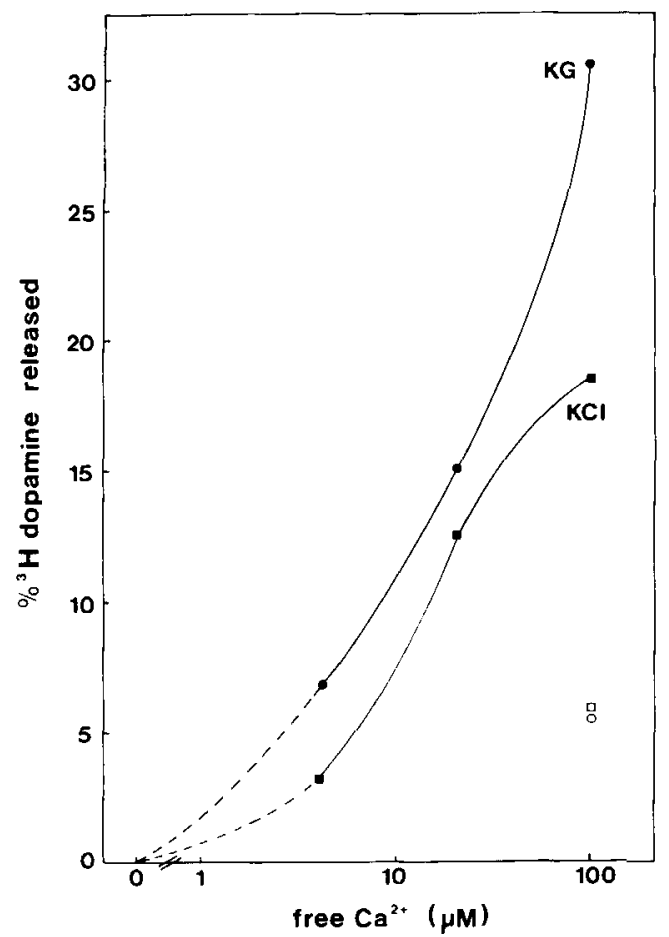

FIG. 3. Comparison of $\left[{ }^{3} \mathrm{H}\right]$ dopamine secretion induced by $\mathrm{Ca}^{2+}$ in glutamate- or chloride-containing medium. Preloaded PC12 cells were permeabilized in the absence of $\mathrm{Ca}^{2+}$ with $\alpha$-toxin in potassium glutamate (KG) buffer or in the same buffer containing chloride instead of glutamate. After $30 \mathrm{~min}$ at $30^{\circ} \mathrm{C}$ the buffer was completely exchanged for fresh one supplemented with the given free $\mathrm{Ca}^{2+}$ concentrations. After $\mathbf{1 0}$ min radioactivity was measured in the supernatant and in the cell lysate. The release observed in the absence of $\mathrm{Ca}^{2+}$ (in potassium glutamate buffer $8.9 \%$ for controls and $8.1 \%$ in $\alpha$-toxin-treated samples, and in $\mathrm{KCl}$ buffer $15 \%$ and $19 \%$, respectively, $n=2$ ) was subtracted. Results are means of two experiments.
ATP was added. The marked increase of dopamine release at low $(1-4 \mu M) \mathrm{Ca}^{2+}$ concentrations with $\mathrm{Mg}^{2+}$ alone suggests that the effect of $\mathrm{Mg}^{2+}-\mathrm{ATP}$ (Fig. 4a) is due to $\mathrm{Mg}^{2+}$ rather than to ATP. At higher $\mathrm{Ca}^{2+}$ concentrations (above $20 \mu M$ ) $\mathrm{Mg}^{2+}$ did not augment dopamine release (see also Fig. 2a).

When cells first permeabilized with $\alpha$-toxin in buffer with glutamate replaced by chloride were stimulated with $10 \mu M \mathrm{Ca}^{2+}$ with or without $5 \mathrm{mM} \mathrm{Mg}^{2+}$ ATP in addition to $1 \mathrm{~m} M$ free $\mathrm{Mg}^{2+}, \mathrm{Mg}^{2+}$ alone was much more effective than $\mathrm{Mg}^{2+}$-ATP in augmenting the $\mathrm{Ca}^{2+}$-elicited release (Fig. 5).

Effects of TFP and group-specific reagents on $\mathrm{Ca}^{2+}$ induced dopamine release from permeabilized PC1 2 cells

A possible involvement of calmodulin in the release process was studied using TFP as an antagonist. Table 2 shows that 1 or $10 \mu M$ TFP had little or no effect on $\left[{ }^{3} \mathrm{H}\right]$ dopamine release, induced by 2 or $20 \mu M$ free $\mathrm{Ca}^{2+}$ alone. However, $10 \mu M$ TFP itself increased basal release in cells not treated with $\alpha$-toxin and in permeabilized cells (Table 2). Thus the increased release of dopamine observed with $10 \mu M$ TFP by $2 \mu M$ $\mathrm{Ca}^{2+}$ is due to an additive effect of both substances (Table 2). Preincubation with $1 \mu M$ TFP 20 min before the permeabilization and stimulation procedure also failed to modify $\left[{ }^{3} \mathrm{H}\right]$ dopamine release by 2 and $20 \mu M$ free $\mathrm{Ca}^{2+}$ (Table 2).

Table 3 shows that drugs that block -SH (PHMB, DTNB, NEM) and -OH groups (NEM) did not affect $\mathrm{Ca}^{2+}$-induced $\left[{ }^{3} \mathrm{H}\right]$ dopamine release by permeabilized PC12 cells. Two hundred micromolar NEM doubled the $\left[{ }^{3} \mathrm{H}\right]$ dopamine release in nonpermeabilized cells as well as in permeabilized cells in the absence of $\mathrm{Ca}^{2+}$, probably due to leakage of catecholamines.

\section{DISCUSSION}

Permeabilization of secretory cells is a promising tool for elucidating the final events in stimulusexocytosis coupling. Permeabilization not only by high-voltage discharge (Baker and Knight, 1978) or by saponins (Dunn and Holz, 1983; Brooks and Treml, 1983a; Wilson and Kirshner, 1983) but also by $\alpha$ toxin from Staphylococcus aureus can be used to gain access to the cytoplasm (Ahnert-Hilger et al., 1985a, $b$; Bader et al., 1986; Lind et al., 1987). The toxin produces stable pores in the plasma membrane that are too small to let the monomer pass and attack subcellular organelles (Füssle et al., 1981; for review see Bhakdi et al., 1981; Bhakdi and Tranum-Jensen, 1987). Micromolar concentrations of $\mathrm{Ca}^{2+}$ are an absolute requirement for exocytotic release in most, if not all, permeabilized secretory cells. ATP is also essential for catecholamine release from primary cultures of bovine adrenal medullary chromaffin cells but PC12 cells do not require additional substances. This was shown by the present experiments in which ATP and other small endogenous compounds were effec- 


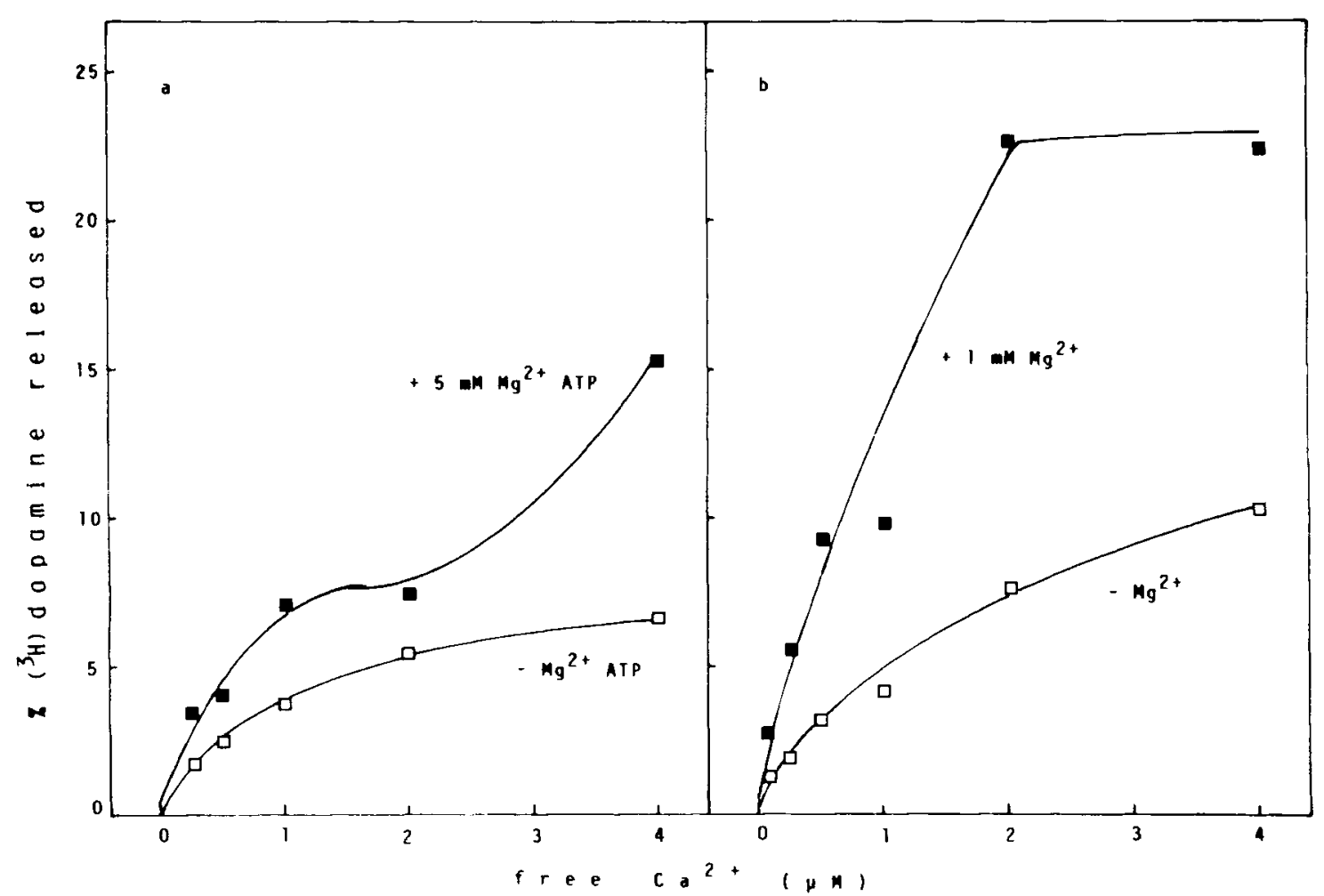

FIG. 4. Effect of free $\mathrm{Mg}^{2+}$ on $\mathrm{Ca}^{2+}$-induced $\left[{ }^{3} \mathrm{H}\right]$ dopamine release by permeabilized $\mathrm{PC} 12$ cells. Preloaded $\mathrm{PC} 12$ cells in suspension were treated with $\alpha$-toxin in potassium glutamate buffer plus or minus $\mathrm{Mg}^{2+}$-ATP (a) or $\mathrm{Mg}^{2+}$ (b). The abscissa gives the free Ca ${ }^{2+}$ concentration. Release in the absence of $\mathrm{Ca}^{2+}$ in $\alpha$-toxin-treated cells was subtracted. $\alpha$-Toxin treatment in the absence of $\mathrm{Ca}^{2+}$ does not result in a significant increase as compared to untreated controls. $8: \mathrm{Ca}^{2+}$-induced release in the absence or presence of $5 \mathrm{mM} \mathrm{Mg}^{2+}$-ATP, Addition of $5 \mathrm{mM}$ ATP to potassium glutamate buffer containing $5 \mathrm{mM} \mathrm{Mg^{2+ }}$ resulted in a free $\mathrm{Mg}^{2+}$ concentration of about $0.2 \mathrm{mM}$. $\alpha-$ Toxinpermeabilized cells without $\mathrm{Ca}^{2+}$ released $13.3 \%$ and $13.6 \%(n=2)$ dopamine in the absence or presence of $\mathrm{Mg}^{2+}-\mathrm{ATP}$, respectively. b: $\mathrm{Ca}^{2+}$-induced release in the absence or presence of $1 \mathrm{mM}$ free $\mathrm{Mg}^{2+}$. $\alpha$-Toxin-permeabilized cells without $\mathrm{Ca}^{2+}$ released $15.6 \%$ and $16 \%$ $(n=2)$ dopamine in the absence or presence of $\mathrm{Mg}^{2+}$, respectively.

tively washed out from the $\alpha$-toxin-permeabilized PC 12 cells by a procedure previously applied to adrenal medullary chromaffin cells (compare Bader et al., 1986, and Results, this article). Even after more vigorous washout procedures, or removal of glutamate from the media, as a potential source for mitochondrial ATP production, the PC12 cells still did not depend on ATP for their dopamine release. Similarly, in earlier experiments on intact PCI 2 cells, inhibition of ATP production by glycolysis or oxidative phosphorylation did not decrease dopamine release (Reynolds et al., 1982). On the other hand, the permeabilized adrenal medullary chromaffin cell (for references see above) and the intact cell both need ATP for catecholamine release (Rubin, 1969; Kirshner and Smith, 1969).

ATP-independent exocytosis has also been shown in sea urchin eggs, using a preparation of cortical vesicles attached to the inner surface of the plasma membrane (isolated cortices) or electrically permeabilized eggs (Vacquier, 1975; Baker and Whitaker, 1978). Similarly, isolated cortices from paramecia do not require ATP for exocytosis of trichocysts (Vilmart-Seuwen et al., 1986). In these cells the vesicles are aligned to the plasma membrane (eggs) or even docked to it (paramecia) to allow immediate release. A preferential location of secretory vesicles near the plasma membrane has also been observed in PC12 cells (Watanabe et al., 1983) whereas in adrenal medullary chromaffin cells the secretory vesicles are distributed throughout the cytoplasm (for references see Bader et al., 1981). This clearly indicates that intracellular vesicle transport may not be necessary in cells that do not depend on ATP during stimulation for exocytosis. The ATP requirement for intracellular vesicle transport is well established (Adams, 1982; Allen et al., 1985; Vale et al., 1985). The absence of a requirement for exocytotic membrane fusion agrees with the finding that isolated secretory vesicles undergo $\mathrm{Ca}^{2+}$-induced fusion without added ATP (Gratzl et al., 1980; Ekerdt et al., 1981). Thus in ATP-dependent cells, vesicle movement driven by ATP most likely precedes exocytotic membrane fusion.

The target for $\mathrm{Ca}^{2+}$ during exocytotic membrane fusion is probably proteinaceous in nature. Antibodies to calmodulin inhibit exocytosis in isolated cortices of sea urchin eggs (Steinhardt and Alderton, 1982) and block catecholamine secretion when transferred 


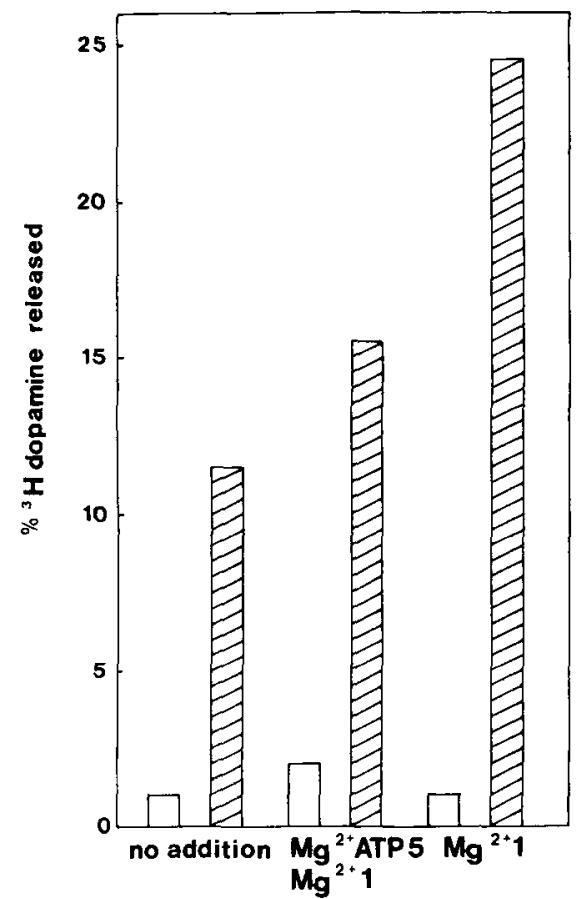

FIG. 5. Effects of $\mathrm{Mg}^{2+}$ with and without ATP on $\mathrm{Ca}^{2+}$-induced dopamine release by permeabilized PC12 cells. Preloaded PC12 cells were permeabilized with $\alpha$-toxin $(180 \mathrm{U} / \mathrm{ml}$ ) in KCl buffer (glutamate replaced by chloride) in the absence of $\mathrm{Ca}^{2+}$ either without further addition or in the presence of $1 \mathrm{mM}$ free $\mathrm{Mg}^{2+}$ plus $5 \mathrm{mM}$ $\mathrm{Mg}^{2+}$-ATP or $1 \mathrm{mM}$ free $\mathrm{Mg}^{2+}$ for $30 \mathrm{~min}$ at $30^{\circ} \mathrm{C}$. The buffer was exchanged for a fresh one with the same constituents and supplemented with $10 \mu M$ free $\mathrm{Ca}^{2+}$. After $10 \mathrm{~min}\left[{ }^{3} \mathrm{H}\right]$ dopamine was estimated in the medium and in the cell lysate. Release in the absence of $\mathrm{Ca}^{2+}$ (about $20 \%$ ) was subtracted. Cells treated with $\alpha$ toxin in $\mathrm{KCl}$ buffer exhibited an increased release in the absence of $\mathrm{Ca}^{2+}$ as compared to cells in potassium glutamate buffer (see also Fig. 3). The release was lower in the presence of either $\mathrm{Mg}^{2+}$ ATP or $\mathrm{Mg}^{2+}$. The open bars represent controls, the hatched bars $\alpha$-toxin-treated cells $(n=2)$.

TABLE 2. Effect of TFP on $\mathrm{Ca}^{2+}$-induced release of dopamine by permeabilized $P C 12$ cells

\begin{tabular}{|c|c|c|c|}
\hline \multirow{2}{*}{$\begin{array}{l}\text { Treatment } \\
\text { of cells }\end{array}$} & \multicolumn{3}{|c|}{$\left[{ }^{3} \mathrm{H}\right]$ Dopamine released $(\%)$} \\
\hline & $\mathrm{No} \mathrm{Ca}^{2+}$ & $2 \mu M \mathrm{Ca}^{2+}$ & $20 \mu M \mathrm{Ca}^{2+}$ \\
\hline - & 0.4 & 5.2 & 12.2 \\
\hline $1 \mu M$ TFP & ND & 6.2 & 10.8 \\
\hline $10 \mu M$ TFP & 5.8 & 7.0 & 15.2 \\
\hline- & $1.9 \pm 0.07$ & $5.3 \pm 0.2$ & $18.1 \pm 0.7$ \\
\hline $1 \mu M$ TFP & $0.2 \pm 0.02$ & $4.4 \pm 0.1$ & $16.3 \pm 0.6$ \\
\hline
\end{tabular}

In (a), cells preloaded on plates were permeabilized with $\alpha$-toxin $(150 \mathrm{U} / \mathrm{ml})$ with or without the indicated free $\mathrm{Ca}^{2+}$ concentration $\left(20 \mathrm{~min}, 37^{\circ} \mathrm{C}\right)$ in the presence or absence of the given amount of TFP. Release in untreated samples (without toxin and TFP) was subtracted $(13.4 \% \pm 1.4 \%, \mathrm{SD}, \mathrm{n}=4)$.

In (b) the experiment was carried out as described under (a) but $1 \mu M$ TFP was present during the last $20 \mathrm{~min}$ of the loading period. Release in the absence of $\alpha$-toxin $(16.4 \% \pm 1 \%, \mathrm{SD}, \mathrm{n}=6)$ was subtracted. Values are the means of two (a) or three $\pm \mathrm{SD}$ (b) experiments.
TABLE 3. Effects of PHMB, DTNB, and NEM on $\left.{ }^{3} \mathrm{H}\right]$ dopamine release induced by $20 \mu \mathrm{M}$ free $\mathrm{Ca}^{2+}$ in permeabilized PCI 2 cells

\begin{tabular}{lcc}
\hline \multirow{2}{*}{$\begin{array}{c}\text { Treatment } \\
\text { of cells }\end{array}$} & \multicolumn{2}{c}{ [3]Dopamine released (\%) } \\
\cline { 2 - 3 } \multicolumn{1}{c}{-} & $\mathrm{No} \mathrm{Ca}^{2+}$ & $20 \mu M \mathrm{Ca}^{2+}$ \\
\hline -Toxin & 8.0 & 9.3 \\
$200 \mu M$ PHMB & 9.9 & 22.9 \\
$\alpha$-Toxin $+200 \mu M$ PHMB & ND & 10.7 \\
$200 \mu M$ DTNB & 11.6 & 22.5 \\
$\alpha$-Toxin $+200 \mu M$ DTNB & ND & 9.7 \\
$200 \mu M$ NEM & 13.4 & 26.9 \\
$\alpha$-Toxin $+200 \mu M$ NEM & ND & 21.1 \\
\hline
\end{tabular}

Preloaded cells were treated with $\alpha$-toxin $(150 \mathrm{U} / \mathrm{ml})$ with or without $200 \mu M$ of the indicated drug in the presence or absence of $20 \mu M$ free $\mathrm{Ca}^{2+}$. Values are means of duplicate determinations.

to chromaffin cells using erythrocytes as a vehicle (Kenigsberg and Trifaró, 1984). Experiments with TFP also suggested that calmodulin or related proteins are involved in catecholamine release from chromaffin cells (Kenigsberg et al., 1982; Brooks and Treml, 1983b). However, $\mathrm{Ca}^{2+}$-induced exoytosis from permeabilized PC12 cells (this study) was not affected by TFP. This agrees with similar observations using electrically or detergent-permeabilized cells (Baker and Knight, 1981; Brooks and Treml, 1984). The findings neither prove nor exclude participation of the $\mathrm{Ca}^{2+}$-binding calmodulin in secretion but they exclude its involvement in the final step of exocytosis in chromaffin cells. The involvement of other proteins with functional $-\mathrm{OH}$ or $-\mathrm{SH}$ groups is ruled out by the use of group-specific reagents (Baker and Knight, 1981 ; this study).

An effect of $\mathrm{Mg}^{2+}$ on $\mathrm{Ca}^{2+}$-induced hormone release from permeabilized chromaffin cells is difficult to obtain since these cells depend on $\mathrm{Mg}^{2+}$-ATP for release. Yet $\mathrm{Mg}^{2+}$ in high amounts inhibited $\mathrm{Ca}^{2+}$-induced release in chromaffin cells permeabilized by high-voltage discharge (Knight and Baker, 1982). The experiments in this study were initially undertaken to look for inhibitory effects of $\mathrm{Mg}^{2+}$ in $\alpha$-toxin-permeabilized PC12 cells. It is interesting to note that in the permeabilized PC12 cells $\mathrm{Mg}^{2+}$ enhanced secretion induced by low concentrations of $\mathrm{Ca}^{2+}$. The possibility that $\mathrm{Mg}^{2+}$ facilitates the attachment of the secretory vesicles to the cell membrane before fusion and that exocytotic hormone release is subsequently triggered by $\mathrm{Ca}^{2+}$ will be investigated in future work.

Note added in proof: After this paper was submitted it was reported by S. C. Peppers and R. W. Holz [J. Biol. Chem. 261, 14665-14669 (1986)] that when PC12 cells were permeabilized for $6 \mathrm{~min}$ with digitonin and then stimulated for 18 min with micromolar $\mathrm{Ca}^{2+}$, the absence of $\mathrm{Mg}^{2+}-\mathrm{ATP}$ during permeabilization only slightly inhibited $\mathrm{Ca}^{2+}$-dependent secretion but its absence also during permeabilization 
and incubation with $\mathrm{Ca}^{2+}$ resulted in a further decline in norepinephrine release. This disparity with the present study cannot at present be assessed but the rapid decrease in the secretory response of digitonin-treated cells and the inhibitory effect of digitonin as observed in electrically permeabilized cells (Baker and Knight, 1981) could be involved.

Acknowledgment: The excellent technical assistance of Mrs. I. Lind and Mr. P. Welk is gratefully acknowledged. We are indebted to B. Mader for typing the manuscript. This study was supported by Deutsche Forschungsgemeinschaft (Gr 681) and by Forschungsschwerpunkt No. 24 of the State of Baden-Württemberg.

\section{REFERENCES}

Adams R. J. (1982) Organelle movement in axons depends on ATP. Nature 297, 327-329.

Ahnert-Hilger G., Bhakdi S., and Gratzl M. (1985a) Alpha-toxin permeabilized rat pheochromocytoma cells: a new approach to investigate stimulus-secretion coupling. Neurosci. Lett. 58, $107-110$.

Ahnert-Hilger G., Bhakdi S., and Gratzl M. (1985b) Minimal requirements for exocytosis: a study using $\mathrm{PC} 12$ cells permeabilized with staphylococcal alpha-toxin. J. Biol. Chem. 260, 12730-12734.

Allen R. D., Weiss D. G., Hayden J. H., Brown D. T., Fujiwake H., and Simpson M. (1985) Gliding movement of and bidirectional transport along single native microtubules from squid axoplasm: evidence for an active role of microtubules in cytoplasmic transport. J. Cell Biol. 100, 1736-1752.

Bader M. F., Ciesielski-Treska J., Thiersé D., Hesketh J. D., and Aunis D. (1981) Immunocytochemical study of microtubules in chromaffin cells in culture and evidence that tubulin is not an integral protein of the chromaffin granule membrane. $J$. Neurochem 37, 917-933.

Bader M. F., Thiersé D., Aunis D., Ahnert-Hilger G., and Gratzl M. (1986) Characterization of hormone and protein release from alpha-toxin permeabilized chromaffin cells in primary culture. J. Biol. Chem. 261, 5777-5783.

Baker P. F. and Knight D. E. (1978) Calcium-dependent exocytosis in bovine adrenal medullary cells with leaky plasma membranes. Nature 276, 620-622.

Baker P. F. and Knight D. E. (1981) Calcium control of exocytosis and endocytosis in bovine adrenal medullary cells. Philos. Trans. R. Soc. Lond. [Biol.] 296, 83-103.

Baker P. F. and Whitaker M. J. (1978) Influence of ATP and calcium on the cortical reaction in sea urchin eggs. Nalure 276, 513-515.

Bhakdi S. and Tranum-Jensen J. (1987) Damage to mammalian cells by proteins that form transmembrane pores. Rev. Physiol Biochem. Pharmacol. 107, 147-223.

Bhakdi S., Füssle R., and Tranum-Jensen J. (1981) Staphylococcal alpha-toxin: oligomerization of hydrophilic monomers to form amphiphilic hexamers induced through contact with deoxycholate detergent micells. Proc. Natl. Acad. Sci. US.478, 54755479.

Brooks J. C. and Treml S. (1983a) Catecholamine secretion in chemically skinned cultured chromaffin cells. $J$. Neurochem. 40, 468-473.

Brooks J. C. and Treml S. (1983b) Effect of trifluoperazine on catecholamine secretion by isolated bovine adrenal medullary chromaffin cells. Biochem. Pharmacol. 32, 371-373.

Brooks J. C. and Treml S. (1984) Effect of trifluoperazine and calmodulin on catecholamine secretion by saponin-skinned cultured chromaffin cells. Life Sci. 34, 669-674.

Dunn L. A. and Holz R. W. (1983) Catecholamine secretion from digitonin-treated adrenal medullary chromaffin cells. $J$. Biol. Chem. 258, 4989-4993.
Ekerdt R., Dahl G., and Gratzl M. (1981) Membrane fusion of secretory vesicles and liposomes: two different types of fusion. Biochim. Biophys. Acta 646, 10-22.

Flodgaard H. and Fleron B. (1974) Thermodynamic parameters for the hydrolysis of inorganic pyrophosphate at $\mathrm{pH} 7.4$ as a function of $\left(\mathrm{Mg}^{2+}\right),\left(\mathrm{K}^{+}\right)$, and ionic strength determined from equilibrium studies of the reaction. J. Biol. Chem. 249, 3465-3470.

Füssle R., Bhakdi S., Sziegoleit A., Tranum-Jensen J., Kranz T., and Wellensiek H. J. (1981) On the mechanism of membrane damage by $S$. aureus a-toxin. J. Cell Biol. 91, 83-94.

Gratzl M. and Dahl G. (1978) Fusion of secretory vesicles isolated from rat liver. J. Membr. Biol. 40, 343-364.

Gratzl M., Schudt Ch., Ekerdt R., and Dahl G. (1980) Fusion of isolated biological membranes. A tool to investigate basic processes of exocytosis and cell-cell fusion, in Membrane Structure and Function, Vol. 3 (Bittar E. E., ed), pp. 59-92. John Wiley, New York.

Kenigsberg R. L. and Trifaró J. M. (1984) Microinjection of calmodulin antibodies into cultured chromaffin cells blocks catecholamine release in response to stimulation. Neuroscience 14, 335-349.

Kenigsberg R. L., Coté A., and Trifaró J. M. (1982) Trifluoperazine, a calmodulin inhibitor, blocks secretion in cultured chromaffin cells at a step distal from calcium entry. Neuroscience 7, 22772286.

Kirshner N. and Smith W. J. (1969) Metabolic requirements for secretion from the adrenal medulla. Life Sci. 8, 799-803.

Knight D. E. and Baker P. F. (1982) Calcium-dependence of catecholamine release from bovine adrenal medullary cells after exposure to intense electric fields. J. Membr. Biol. 68, 107140.

Lind I., Ahnert-Hilger G., Fuchs G., and Gratzl M. (1987) Purification and application for cell permeabilization of alpha-toxin from staphylococcus aureus. Anal. Biochem. 164, 84-89.

Lowry O. H., Rosebrough N. J., Farr A. L., and Randall R. J. (1951) Protein measurement with the Folin phenol reagent. J. Biol. Chem. 193, 265-275.

Reynolds E. E., Melega W. P., and Harrod B. D. (1982) Adenosine 5 'triphosphate independent secretion from $\mathrm{PC} 12$ phaeochromocytoma cells. Biochemistry 21, 4795-4799.

Rubin R. P. (1969) The metabolic requirements for catecholamine release from the adrenal medulla. J. Physiol. (Lond.) 202, 197209.

Sillen L. G. and Martell A. D. (1971) Stability constants of metalion complexes. Suppl. 1 . The Chemical Society, London. London.

Simon W., Ammann D., Oehme M., and Morf W. E. (1978) $\mathrm{Ca}^{2+}$ selective electrodes. Ann. NY.Acad. Sci. 307, 52-70.

Steinhardt R. A. and Alderton J. M. (1982) Calmodulin confers calcium sensitivity on secretory exocytosis. Nature 295, 154155.

Vacquier V. D. (1975) The isolation of intact cortical granules from sea urchin eggs: calcium ions trigger granule discharge. Dev. Biol. 43, 62-74.

Vale R. D., Schnapp B. J., Reese T. S., and Sheetz M. P. (1985) Organelle, bead, and microtubule translocations promoted by soluble factors from the squid giant axon. Cell 40, 559-569.

Vilmart-Seuwen J., Kersken H., Stürzl R., and Plattner H. (1986) ATP keeps exocytosis sites in primed state but is not required for membrane fusion. An analysis with Paramecium cells in vivo and in vitro. I. Cell Biol. 103, 1279-1289.

Wadström T. (1968) Studies on extracellular proteins from Staphylococcus aureus. IV. Separation of alpha-toxin by isoelectric focusing. Biochim. Biophys. Acta 168, 228-242.

Watanabe D., Torda M., and Meldolesi J. (1983) The effect of $\alpha$ latrotoxin on the neurosecretory PC 12 cell line: electron microscopy and cytotoxicity studies. Neuroscience 10, 10111024

Wilson S. P. and Kirshner N. (1983) Calcium-evoked secretion from digitonin-permeabilized adrenal medullary chromaffin cells. J. Biol. Chem. 258, 4994-5000. 